\title{
The Economic Impact of Labour Mobility in an Enlarged European Union
}

\author{
Thomas Krichel \\ University of Surrey
}

\author{
Paul Levine \\ University of Surrey, \\ and CEPR
}

October 13, 2002

\begin{abstract}
European Union enlargement and the commitment to the free movement of labour within the Union raises the possibility of a substantial East-West wave of migration. This paper addresses three separate issues: first, the economic impact on host and donor countries of migration from a less developed Eastern region to more developed Western region. Here there are, in turn, two aspects: the short-run impact on the level of growth and the long-run impact on growth rates. The second issue is the possible need for migration controls and the final issue concerns winners and losers from migration.
\end{abstract}

JEL Classification: F22, J61, O15

Key words: migration, economic impact, European enlargement, 


\section{Introduction}

The possibility of East-West European migration waves within a more liberal immigration regime has received considerable attention from policymakers and concern has been expressed about the economic and political impact. The political dimensions of migration are important. They are explored in other chapters of this book. This chapter narrowly focuses on the economic issues.

From the perspective of an economist, the migration decision based on the maximization of expected income, the existing wage gap between Western and Eastern European countries and a probability of employment in the West at least as good as in the East suggests large group of potential migrants. This paper assesses the shortrun and long-run economic impact of a laissez-faire migration between the regions, who are the winners and losers and the possible need for migration controls.

The rest of the paper is organised as follows. Section 2 examines recent migration trends from Central and Eastern Europe into the EU (in fact mostly into Germany). Section 3 focuses on the short-run impact of migration from a less developed East into a more developed West. This section draws on Levine (1999) and emphasizes the importance of labour market flexibility in the West for realising economic gains from migration. Section 4 is concerned with the long-run and reviews some recent papers that study the effect on both transitional and long-run growth of migration between undeveloped and developed regions. Section 5 concludes the paper.

\section{Recent Migration Trends in Central and East- ern Europe}

An important part of migration in Central and Eastern Europe (CEE) is the repatriation of ethnic minorities. The most important ethnic migration movement is the movement of ethnic Germans from Poland, Hungary and the C.I.S. countries to Germany. These outflows started already in the $80 \mathrm{~s}$ but intensified in the $90 \mathrm{~s}$. Table 1 shows total numbers of foreign nationals from the CEE countries in selected OECD countries.

However the opening of borders has not yet led to mass migration into the West. In fact the inflows into the West have declined, despite continued liberalisation of movements of persons. The current flows of East-West migration are to a large extent explained by past migration flows that have establish communities. Polish 
and Romanian groups are particularly successful in migrating to the West and have large communities established.

At the time of the overthrow of the communist regimes many observers feared a rapid increase in Central and Eastern European migration to the West, in particular to Western Europe for economic reasons. The dismantling of exit visas and the general issuance of passports allowed workers to migrate to high wage and low unemployment areas in the West. However the majority of workers who considered migration exercised their option early. Therefore migration flows increased until 1991, but they have declined since. For example the migration of Romanians into Germany has been negative since 1993. However ethnic conflicts in the region continue to be sources of actual and potential migration. Note that until 1996, the last year for which data for most countries is available, the number of refugee and asylum seekers has declined. Most CEECs are now considered safe; i.e. any asylum application by nationals of these countries will be rejected. This is another reason why the number of permanent migrants to Western Europe has declined. The number of temporary migrants has increased in the Western countries that border CEECs, in particular Germany and Austria. In addition many CEECs have set up programmes of temporary migration to allow nationals access to human capital that is not available locally.

The CEECs also have also changed their nationality code to allow former citizens to return to the country. Some CEECs like Hungary and the Czech Republic are likely to have ${ }^{1}$ now a positive migration balance. For the most part it appears that this immigration is regional. In recent years migration flows from Ukraine, Kazakhstan, and Siberia into Poland, from the Baltic States into Russia, from Russia and Estonia into Finland all can be described as ethnic return migration. Therefore CEE has become a regional migration pole.

A more recent trend that contributes to the emergence of a regional migration pole is the increase in transit migration. These are mainly flows within the CEECs but, also from outside, of migrants who hope to illegally enter a Western European country. Poland and the Czech Republic are particularly affected by this trend because of their common border with Germany. Some transit migrants use Hungary to reach Austria and a small number try to move to the Scandinavian countries via the Baltic states. Many attempts at transit migration fail and some transit migrants stay to work in the informal sector of the transit country. There are of course no figures on how wide-spread the problem is. There have been attempts at

\footnotetext{
${ }^{1}$ This is difficult to know because of a lack of reliable data.
} 


\begin{tabular}{lrrrrrrrr} 
& AT & DK & FI & DE & HU & IT & SE & CH \\
Bulgaria & 3.6 & & & 36.0 & 1.5 & & & \\
F. CSFR & 11.3 & & & 29.6 & 3.7 & & & 4.6 \\
Hungary & 10.6 & & .4 & 55.7 & 0.1 & & 2.9 & 3.5 \\
Poland & 18.3 & 5.3 & .7 & 283.4 & 4.3 & 27.4 & 15.9 & 4.4 \\
Romania & 18.5 & 1.1 & & 100.7 & 61.6 & 31.7 & 3.8 & \\
C.I.S. & 2.1 & 2.6 & 17.0 & 54.3 & & & & \\
F. Yug. & 198 & 32.2 & 4.0 & 1297 & 14.9 & 94.6 & 36.6 & 305.0 \\
\hline \% of immi. & 50.7 & 17.4 & 29.9 & 24.4 & 60.4 & 14.0 & 11.2 & 23.7
\end{tabular}

Table 1: Foreign Nationals in thousands who are nationals of central and eastern European countries in selected European OECD countries, latest available year (1996, except for Austria for which the year is 1991).

international collaborative efforts - between the destination countries and the transit countries - to control the problem.

Between 1994 and 1996, Bulgaria, the Baltic Countries, the Czech and Slovak Republics, Hungary, Poland, Romania, and Slovenia presented their candidature to access the European Union. The population of these countries is over 100 million strong, which is about 30 per cent of the current EU countries. The control of migration flows that could arise is a major challenge for the integration process and free movement of persons may have to be introduced gradually.

Source: SOPEMI (1998)

\section{The Short-Run Economic Impact}

The pioneering work on the migration decision and its impact on the donor and host regions was undertaken in a LDC rural- industrial context by Harris and Todaro (1970), henceforth HT. They offer a macroeconomic model comprising a developed urban sector and an undeveloped rural sector in which wages were rigid for the former, but flexible for the latter. The potential rural-to-urban migrant then maximizes her expected income taking into account the probability of being unemployed after migrating which HT assumed to be one minus the unemployment rate. In this setup urban unemployment provides the equilibrating mechanism to limit the inflow of migrants. The HT analysis yields predictions that the rate of migration increases as the urban-rural wage differential increases and the urban unemployment 
rate decreases.

It is clear that an analysis of East-West European migration differs from the HT framework, in a number of respects. First, European migration takes place largely between industrial regions which are characterised by apparently huge differences in physical capital per worker. Second, neither bloc is characterised by labour market clearing, unlike the HT case of a market-clearing rural sector. Indeed there is likely to be higher unemployment in the donor than in the host country. Third, human capital considerations are of crucial importance: the impact of highly skilled welleducated workers on the West will be quite different from that if their skills turn out to be lower or irrelevant.

Levine (1999) develops a HT type model $^{2}$ of East-West migration in which labour market imperfections prevent market clearing in both blocs. The model applies to the short-run in the sense that the capital and prices are fixed. Wages are allowed to respond to labour market pressures. The model encompasses two extremes of perfectly flexible wages with full employment on the one hand, and the HT scenario where the wage in the host country is fixed, on the other. Before reviewing the findings of this paper it is instructive to first consider the opposite extreme to HT: the case of perfectly flexible wages.

\section{Perfectly Flexible Wages.}

Consider two blocs East and West. To keep thing simple assume that the regions produce the same composite output and the labour force is equal. Capital of both the physical and human variety are given and higher in the West. Both average and marginal output per worker is therefore higher in the West. Figure 1 shows what happens when migration from East to West occurs. The Eastern workforce (fully employed by assumption) falls from OA by an amount HA increasing the Western workforce by the same amount $\mathrm{AB}=\mathrm{HA}$. The area under the marginal product of labour (MPL) curves give total output and the MPL(West) is higher than its Eastern counterpart MPL(East) because physical and human capital is higher in the West. Ignore for the moment human capital differences; then 1 unit of Eastern labour is equivalent to 1 unit of Western labour. Output then rises by an amount KDBA in the $\mathrm{W}$ and falls by an amount FJAH=ECBA in the East. The net increase in output is therefore given by the shaded region KDCE. The real wage falls in the West and rises in the East. If there are costs associated with migration and migrants maximize income net of costs, migration will cease before wages are equalized. Figure 1 shows

\footnotetext{
${ }^{2}$ Ghatak, Levine, and Wheatley Price (1996) provide a survey of and extensions to the HT class of models. Krichel and Levine (1999) extend HT to allow for some wage flexibility.
} 
the case of factor price equalization where migration costs are zero and migration leads to equal wage rates. The winners are the migrants and Western capitalists; losers are the original Western workers and Eastern capitalists. Figure 1 assumes that human capital per worker is the same in the two blocs. If this is not the case however and the Eastern migrant has a lower skill level than the Wester indigenous worker there is a further effect: the MPL (West) curve shifts downwards thereby reducing the net output gains from East-West migration.

\section{FIGURE 1 HERE}

\section{Migration with Wage Rigidity.}

The general case of some wage flexibility which encompasses the two extremes we have discussed is illustrated in figure 2 taken from Levine (1999). The labour supply curves (which, following Layard, Blanchard, Dornbusch, and Krugman (1994), we refer to as the 'bargained real wage' or BRW curves) and the labour demand curves (the marginal product of labour, MPL) are shown for the two blocs. Upward-sloping BRW curves are consistent with a number of theories of wage determination including the monopoly union model, bargaining, and efficiency wage theories. OA is the total labour force in East and West prior to migration (assumed to be equal). As a result of migration equal to $\mathrm{HA}=\mathrm{AB}$, with some real wage flexibility, the BRW (West) shifts to the right and employment rises by WW. Similarly the BRW (East) shifts to the left and employment falls by EE. The welfare implications of East-West migration - which we analyze in more detail in the next section - can be assessed by comparing the increase in Western output HJWW with the decrease in the East FGEE. We have illustrated the case where WW, EE and the real wage flexibility in the two regions are about equal. Then the net output gains are positive; in general, however, the output effects are crucially dependent on the degree of real wage flexibility in the two labour markets.

\section{FIGURE 2 HERE}

Figure 2 assumes that human capital per worker is the same in both blocs and subsequently there is no drop in the average post- migration human capital in the West. If however migration lowers the average human capital in the West the MPL (West) curve shifts downwards thereby reducing the net output gains from EastWest migration.

\section{The Migration Decision}

Assume that the potential migrant is risk-neutral and faces uncertainty over the 
possibility of employment in the West. Assume that the latter decreases as the unemployment rate increases. Denote by $C_{p}$ the private costs per period of migration, this include the transport cost to West, the cost of language training, searching for job, and more generally a monetary evaluation of the inconvenience of living in a foreign country as opposed to be living at home.

Let $p_{W}$ be the probability of employment in the West, $w_{W}$ the Western wage rate and $b_{W}$ income of the unemployed. Then the expected income after migration is $p_{w} w_{W}+\left(1-p_{W}\right) b_{W}+C_{p}$. Migration will then continue until in a migration equilibrium this expression equals the expected income in the East; ie,

$$
p_{W} w_{W}+\left(1-p_{W}\right) b_{W}+C_{p}=p_{E} w_{E}+\left(1-p_{E}\right) b_{E}
$$

The unemployment rates East and West, as in the HT model, then act as an equilibrating mechanism that limits migration and stabilizes post-migration workforce in the two regions. A wave of East-West migration increases (decreases) the unemployment rate in the West (East). This reduces the expected income differential until the migration equilibrium, (1), is reached and migration ceases.

Factors which will reduce the size of the migration flow are: high private costs of migration, unequal treatment of immigrants in the Western labour markets and unequal access to unemployment income support. However these calculations ignore the irreversibility of the migration decision and the option to wait. From the 'new investment theory' of Dixit and Pindyck (1994) we know that the migration equilibrium in an environment of exogenous uncertainty coupled with irreversibility in the private costs of migration will make the potential Eastern citizen far more conservative in her decision to migrate. These considerations will lead to lower migration flows than that predicted by (1).

\section{The Welfare Analysis of Migration}

Consider a mythical utilitarian social planner concerned with Europe's total GDP net of the costs of migration. This implies a social welfare function of the form

$$
S(M)=Y_{E}+Y_{W}-M\left(C_{p}+C_{s}\right)
$$

where $\mathrm{M}$ is the number of migrants, $Y_{E}$ and $Y_{W}$ denote output in the two blocs and $C_{p}$ and $C_{s}$ are private and social costs per migrant respectively. Then the mythical social planner by maximising $S(M)$ with respect to $M$ chooses an optimal migration rate and with it an optimal allocation of Europe's workforce between East and West. Two results are then obtained in Levine (1999): Result 1 tells us that 
the fundamental theorem of welfare holds for migration. This implies that once the mythical central planner has made the socially optimal choice, it is not possible to improve the welfare of one bloc without reducing the welfare of another block. Result 2 sets out the necessary and sufficient condition for laissez-faire migration to exceed the social optimum. 


\section{Result 1}

Under full wage flexibility and in the absence of externalities the laissezfaire migration rate is socially optimal.

\section{Result 2}

With wage rigidities in the two blocs laissez-faire migration is excessive relative to the social optimum if and only if

$$
\frac{d S}{d M}=w_{E} \frac{d L_{E}}{d M}+w_{W} \frac{d L_{W}}{d M}<C_{p}+C_{s}
$$

\section{at the laissez-faire migration equilibrium.}

In (3) the first term is the marginal decrease in output in the East with respect to the migration level; the second term is the marginal increase in output in the West. The combined left-hand-side of the inequality is the shaded area in figure 2. The right-hand-side of (3) is the marginal cost both private (internalised by the migrant) and social (the externality not internalised by the migrant).

An interesting possibility immediately arises from result 2. A combination of high real wage flexibility in the West, low flexibility in the East and low migration costs (private plus social) can lead to laissez-faire migration being below the social optimum. This leads to a large increase in employment and output in the West alongside a low employment and output loss in the East. We pursue this case further in numerical simulations to which we now turn.

\section{The Laissez-Faire and Social Optimum Outcomes: Numerical Results}

The crucial parameters that determines the extent of welfare gains are the semielasticities of the wage with respect to the unemployment rate in the two blocs, $\eta_{E}$ and $\eta_{W}$ and the ratio of Eastern to Western human capital $H_{E} / H_{W}$. In figures 3 and 4 , the Western elasticity and human capital per worker is set at $\eta_{W}=H_{W}=1$. The sizes of the two workforces are assumed to be equal and normalized at unity. Figure 3 graphs the social welfare function $S(M)$ with against the migration rates for three values of the Eastern elasticity, $\eta_{E}=1$ (the central value) and two alternatives $\eta_{E}=0.5$ and $\eta_{E}=1$. The migration level $M$ therefore becomes a migration rate. Social costs of migration are ignored throughout this section thus understating the need for immigration controls in the West. However the costs of immigration controls are also ignored which tips the balance in the opposite direction towards laissez-faire.

When the model is calibrated using $\eta_{E}=1.0$, the socially optimal migration rate is around $M=0.25$ compared with the laissez-faire equilibrium $M=0.28$. For this 
case there is a clear case for immigration controls. But the two cases where wage flexibility is greater in the West, $\eta_{E}=0.75,0.5$ as opposed to $\eta_{W}=1$ illustrates the possibility alluded to above that laissez-faire migration can be too low compared with the social optimum.

FIGURE 3 HERE

Figure 4 examines the robustness of this result by relaxing the assumption that the level of human capital is the same in both blocs. From a large number of numerical simulations undertaken we report the case $\eta_{W}=1, \eta_{E}=0.5$ and values $\bar{H}_{E}=1.0,0.9,0.8$ and $\bar{H}_{W}=1$. For these quite small differences in East-West human capital levels the social optimum falls below the laissez-faire migration level even for the low real wage elasticity $\eta_{E}=0.5$ in the East. These results suggest that if Eastern underdevelopment originates in part from lower human rather than physical capital, then laissez-faire migration will lead to excessive levels of migration, even from the narrow economic perspective of this paper, and the need for some form of immigration controls.

FIGURE 4 HERE

\section{Migration and Growth}

A vast theoretical and empirical literature has emerged since the 1980's which has transformed the way economists think about growth. The pioneering research was Romer (1986) and Romer (1990). New growth theory contrasts with the earlier neoclassical or old growth theory of Solow (1956) which invoked exogenous technical change to explain sustained long-term growth. By contrast the focus of the new endogenous growth (EG) theory is on how the consumption and savings decisions of households, the investment decisions of firms, and public policy in various forms, determine long-term growth. Whilst the neoclassical model could be described as a model with long-run growth, the new literature offers a number of possible models of long-run growth.

The EG literature can be usefully be divided into two broad strands: the first builds on Romer (1986), is closest to the classical tradition and emphasises capital accumulation as the engine of growth with capital broadly defined to include human and physical components. In the second broad strand of the literature following Romer (1990) the discovery of new goods and of new processes provides the engine of growth. R\&D activity provides blueprints for these innovations and a feature of 
this literature is the attempt to understand the economic forces that drive R\&D.

This section reviews three papers that draw upon this literature in order to assess the impact of migration on growth. The first two papers Mountford (1997) and Faini (1996) use models in the neo-classical tradition where migration affects transitional growth, but long-run growth is exogenous. The third paper, Lundborg and Segerström (1998) studies migration in the context of an EG model driven by R\&D activity.

A standard argument is that migration leaves the lowers growth in the source economy when the highly skilled workers emigrate. Mountford (1997) addresses this question using a model where human capital is crucial to transitional growth. The amount of human capital in any period depends on the decision of households to acquire education. The prospect of higher wages through emigration stimulates the acquisition of human capital and therefore enhances growth. This effect can be stronger than the direct effect of emigration. The direct effect of migration reduce growth because there is a reduction in the supply of skilled labour and a decline in aggregate demand. A brain drain may therefore actually enhance growth in the source economy.

Faini (1996) is more concerned with the convergence His concern is whether migration increases or decreases inequality between regions. He develops a tworegion model of migration. The population in each region is modelled through a two-period overlapping generations model. Consumers are endowed with a unit of labour in youth only. In each period of her live, a consumer $i$ derives utility from a consumable good that is interregionally traded. Consumption is multiplied by a parameter $\theta^{i} \geq 1$ which depends on the location of the consumer. If she migrates, $\theta^{i}$ falls to one. This introduces a cost of migration. $\theta$ is allocated between individuals according to a Pareto distribution. The fraction of the young that will decide not to migrate can then be written as a function of the ratio of wages in the two regions only, with the added convenience of a constant elasticity $\epsilon$.

There are two sectors of production. Production in the non-traded intermediate commodity depends on the capital stock in that sector only with a constant elasticity $\phi$. Returns to scale are increasing if $\phi>1$. Firms take the cost of capital as given, but compete in the output market in a Cournot fashion. Production in the traded sector depends on labour, capital and the non-traded intermediary. Since the latter is produced at increasing returns to scale, endogenous growth is possible, but Faini confines the analysis to parameter values for which there is only transitional growth. The capital stock is composed of the traded commodity but adjustment costs prevent perfect capital mobility between regions. The interest rate is exogenous 
and coincides with the discount rate of consumers. Capital depreciation is complete.

Assume initially that the labour force is identical, but that the initial capital stock is not the same. First consider the case without migration. In each region the rental rate is a negative function of the installed capital stock. Therefore the relative rental rate declines when the relative capital stock increases in the North, leading to an inflow of capital to the South. The model is stable and regional convergence occurs.

Now assume that there is labour mobility. The relative rental differential depends negatively on the relative capital stock as before, but it also depends positively on $(1-\phi) \epsilon$. Therefore if the degree of labour mobility is sufficiently high and the returns to scale in the intermediate sector are sufficiently strong, then the model diverges.

Lundborg and Segerström (1998)examine a quality-ladder model of economic growth based on a North-South model in Grossman and Helpman (1991), chapter 12. In such a model, growth is driven by improvements in product quality. In each period, firms engage in an $R \& D$ race to become the quality leader by hiring $R \& D$ workers. A firm that wins the race becomes the only producer in that period. All firms stay in the R\&D race, and every leading firm will be replaced by another. Any firm's probability of becoming the leader depends positively on its own R\&D effort and negatively on the aggregate effort made by all firms. Since all firms are identical, they all make the same R\&D investments and face the same probability to become the product leader.

The world is made up of two regions called North and South. The high-quality products of the North are called "high-tech", only Northern firms can produce them. The products of the South are called "low-tech". The Northern firms could produce them but they will not do so because production of high-tech products is more profitable. Consumers spend a fixed part of their expenditure on commodities of each region. They benefit from the innovation in both regions through falling commodity prices, therefore the rate of growth of real expenditure is identical in both regions. Southern welfare levels are a constant fraction of northern welfare levels. There is a constant incentive to migrate.

Consider first what happens when some Southern consumers/workers die. To start with this means a reduction of consumer expenditure in the South. ${ }^{3}$ Therefore demand and production of Northern commodities falls and the relative wage of Northern consumers falls. This leads to a fall in Northern expenditure. The fall of

\footnotetext{
${ }^{3}$ It is not clear in the paper what happens to the wealth of the dead consumers.
} 
expenditures leads to a fall in the growth rate because there are reduced incentives to invest in R\&D. All these circumstances reduce Northern welfare. Southern welfare is affected negatively by the fall in growth rate, but it is affected positively through the increase in the relative wage. As far as workers - who receive labour income - in the South are concerned the latter effect dominates the former in simulation evidence presented by the authors. As far as capitalists - who own the stock value of firms - in the South are concerned the growth effect dominates.

Now consider the effect of migration from the South to the North. An R\&D worker is assumed to be more productive in the North than in the South, therefore the growth potential in the world economy increases when labour moves to the North. We also have the effect of a population decrease in the South as discussed in the previous paragraph. In addition we have the impact of the labour supply increase in the North, that puts further pressure on the wages in the North. Firms in the North and South increase R\&D expenditure. But in simulations the resulting increase in growth is not sufficient to make migration beneficial to Northern consumers. Northern workers are worse affected than Northern capitalists. Southern workers benefit from migration; the incentives to migrate are reduced. Thus the welfare effects of migration can be divided into static effects from changes in wages and the terms of trade, and dynamic effects from higher growth. Static distributional effects are as the previous section-Northern workers (excluding new immigrants) and Southern capitalists lose and Northern capitalists, Southern workers and migrants gain. Workers North and South gain from increased growth, but Northern capitalists can lose because more $R \& D$ activity intensifies competition and squeezes profits. Table 2 summarises these results on winners and losers. It should be noted that the whole analysis hinges on the absence of capital mobility. If capital mobility is introduced, the results could be very different.

The net effect of migration is naturally sensitive to parameter values and to the specification of the model. In a rather different North-South (or East-West) model Chui, Levine, and Pearlman (1998) (CLP) set out a North-South trade model with changing patterns of trade in which the South can progress through a number of stages of development. Their model again draws upon Grossman and Helpman (1991), but instead of EG being driven by quality ladders, they follow chapter 11, and adopt a model with expanding varieties of goods, developing it in an number of important directions. ${ }^{4}$ They introduce a second factor of production, skilled labour,

\footnotetext{
${ }^{4} \mathrm{~A}$ previous paper involving the same authors, Currie, Levine, Pearlman, and Chui (1999), develop a more primitive model of stages of development with only one factor of production and no traditional sector.
} 


\begin{tabular}{|l|c|c|}
\hline \hline Groups & Static Effects & Dynamic Effects \\
\hline Northern Workers & Losers & Winners \\
\hline Northern Capitalists & Winners & Losers \\
\hline Southern Workers & Winners & Winners \\
\hline Southern Capitalists & Losers & Winners \\
\hline
\end{tabular}

Table 2: Winners and Losers under Migration: Static and Dynamic Aspects

and include a 'traditional' low-technology sector in both regions. They then allow for the South to differ from the North in three ways. First it is less efficient at adopting the technology available on a world-wide level. Second the speed with which the South learns from the North is less than that in the opposite direction. Third its endowment of human capital is less than that in the North. These three differences, together with the degree of patent protection enjoyed by Northern firms (all exogenous in the model), give rise to four stages of development in the South as possible equilibria: specialisation in the traditional sector; a stage where the South in addition copies Northern innovative goods producing 'product cycles'; a third stage where the South begins to innovate in its own right and finally a stage in which the South, like the North, only innovates.

Although CLP do not examine migration in the context of this model, we can point out two channels through which migration will increase growth and strengthen the dynamic effects. First CLP find that North-South trade results in much larger North-South wage differentials for skilled than for unskilled workers. The former will therefore tend to migrate in larger numbers. A high proportion of them will find their way into R\&D activity enhancing growth. Moreover if Southern R\&D involves copying the reduction in this activity will encourage innovation in the North further. This reasoning suggests the possibility that the pessimistic conclusions of Lundborg and Segerstrom are not robust to the specification of their model, but clearly this is an important area for further research.

\section{Conclusions}

This paper first examined the short-run economic effects of moving to a liberal migration regime in Europe, drawing upon Levine (1999). Although our results would generally indicate that for two regions with the present large differences in GDP per head, the socially optimal level of migration is far less than that under 
laissez-faire, a combination of high wage flexibility in the West, low flexibility in the East and an inefficient technology for controlling immigration can lead to the surprising possibility that laissez-faire migration is too little and no immigration controls are necessary; indeed subsidies may be necessary to encourage migration! Although we should not take this scenario too seriously, not least of all because social costs of migration and distributional issues are ignored, it does highlight the need for more research to be directed at the emerging labour markets in the Eastern European countries and at the technology of immigration control.

The literature on growth and migration is quite recent and limited. Our conclusions on this aspect must therefore be tentative. The 'new-trade, new-growth' literature has established that efficiency gains from free trade become magnified many times when the more efficient allocation of resources leads to growth as well as level effects. One must expect that factor mobility leads to a similar effect. However the theoretical new-growth literature has yet to be matched in size and clarity by its empirical counterpart. As we can see in the discussion of North- South growth models based on quality ladders or expanding varieties, we need to narrow down the range of competing growth models from which to choose before we can begin to assess the effect of migration on growth and draw policy conclusions.

\section{References}

Chui, M., P. Levine, and J. Pearlman (1998). Winners and losers in a NorthSouth model of growth, innovation and product cycles. Discussion paper in economics, University of Surrey.

Currie, D., P. Levine, J. Pearlman, and M. Chui (1999). Phases of imitation and innovation in a North-South endogenous growth model. Oxford Economic Papers.

Dixit, A. K. and R. S. Pindyck (1994). Investment Under Uncertainty. Princeton, New Jersey: Princeton University Press.

Faini, R. (1996). Increasing returns, migration and convergence. Journal of Development Economics 49, 121-136.

Ghatak, S., P. Levine, and S. Wheatley Price (1996). Journal of Economic Surveys 10(2), 159-198.

Grossman, G. and E. Helpman (1991). Innovation and Growth in the Global Economy. Cambridge, Massachusetts.: MIT Press. 
Harris, J. and M. Todaro (1970). Migration, Unemployment and Development. American Economic Review 60, 126-142.

Krichel, T. and P. Levine (1999). The welfare economics of rural to urban migration: The Harris-Todaro model revisited. Journal of Regional Science, forthcoming.

Layard, R., O. Blanchard, R. Dornbusch, and P. Krugman (1994). East-West Migration: the Alternatives. Cambridge, Mass.: MIT Press.

Levine, P. (1999). The welfare economics of immigration control.

Lundborg, P. and P. S. Segerström (1998). The growth and welfare effects of international mass migration. FIEF working paper series, The Trade Union Institute for Economic and Social Research, Stockholm.

Mountford, A. (1997). Can a brain drain be good for growth in the source economy? Journal of Development Economics 53, 287-303.

Romer, P. (1986). Increasing returns and long-run growth. Journal of Political Economy 94, 1002-1037.

Romer, P. (1990). Endogenous technical change. Journal of Political Economy 98, S71-S102.

Solow, R. M. (1956). A contribution to the theory of economic growth. Quarterly Journal of Economics 70(1), 65-94.

SOPEMI (1998). Trends in International Migration. OECD.

Straubhaar, T. and K. F. Zimmermann (1992). Towards a European Migration Policy. CEPR Discussion Paper 641. 
Figure 1. Employment and Output after Migration with Perfectly Flexible Wages

Figure 2. Employment and Output after Migration with Wage Rigidity 
Figure 3. The Socially Optimal Level of Migration and Eastern Wage Flexibility $\eta_{E} \cdot \mathrm{SO}=$ Social Optimum. LF=Laissez- Faire

Figure 4. The Socially Optimal Level of Migration and Eastern Human Capital $H_{E}$ 
AT DK FI DE HU IT $\mathrm{SE} \quad \mathrm{CH}$

\begin{tabular}{|c|c|c|c|c|c|c|c|c|}
\hline Bulgaria & 3.6 & & & 36.0 & 1.5 & & & \\
\hline F. CSFR & 11.3 & & & 29.6 & 3.7 & & & 4.6 \\
\hline Hungary & 10.6 & & .4 & 55.7 & 0.1 & & 2.9 & 3.5 \\
\hline Poland & 18.3 & 5.3 & .7 & 283.4 & 4.3 & 27.4 & 15.9 & 4.4 \\
\hline Romania & 18.5 & 1.1 & & 100.7 & 61.6 & 31.7 & 3.8 & \\
\hline C.I.S. & 2.1 & 2.6 & 17.0 & 54.3 & & & & \\
\hline F. Yug. & 198 & 32.2 & 4.0 & 1297 & 14.9 & 94.6 & 36.6 & 305.0 \\
\hline
\end{tabular}

Foreign Nationals in thousands who are nationals of CEECs 


\begin{tabular}{|l|c|c|}
\hline \hline Groups & Static Effects & Dynamic Effects \\
\hline Northern Workers & Losers & Winners \\
\hline Northern Capitalists & Winners & Losers \\
\hline Southern Workers & Winners & Winners \\
\hline Southern Capitalists & Losers & Winners \\
\hline
\end{tabular}

Winners and Losers under Migration: Static and Dynamic Aspects 